\title{
PENGEMBANGAN MODEL BIMBINGAN TEKNIS BERKELANJUTAN DALAM MENINGKATKAN KOMPETENSI TUTOR PAKET C
}

\author{
Anan Sutisna \\ e-mail: ananplsunj@yahoo.com \\ Pendidikan Luar Sekolah Universitas Negeri Jakarta \\ Jalan Rawamangun Muka Jakarta Timur 13220
}

\begin{abstract}
Abstrak: Penelitian ini bertujuan menemukan sebuah model bimbingan teknis berkelanjutan untuk meningkatkan kompetensi tutor paket $C$ dalam pembelajaran. Alternatif yang dipilih untuk mencapai tujuan penelitian ini yaitu dengan mengembangkan model bimbingan teknis berkelanjutan (bimtekber), fokus pada kompetensi tutor dalam melaksanakan tugas pembelajaran, sehingga sesudah mengikuti bimbingan dapat meningkat kompetensi pembelajarannya. Pengembangan model bimtekber didasarkan pada pemikiran bahwa proses bimtekber yang dilakukan selama ini bersifat parsial, berorientasi pada aspek kognitif dan pelaksanaannya sangat konvensional serta materi tidak sesuai dengan kebutuhan peserta. Penelitian dilaksanakan pada bulan Juli sampai dengan November 2015 di lingkungan Dinas Pendidikan / Sudin Dikmen Kota Jakarta Pusat dan Timur. Model bimbingan teknis berkelanjutan yang dikembangkan menggunakan riset dan pengembangan. Hasil penelitian menunjukkan bahwa model bimtekber perlu diujicoba untuk peningkatan kompetensi pedagogik tutor paket $\mathrm{C}$ yang berstandar nasional.
\end{abstract}

Kata-kata kunci: model bimbingan teknik berkelanjutan, kompetensi, dan andragogi.

\section{DEVELOPMENT OF THE MODEL OF SUSTAINABLE TECHNICAL ASSISTANCE TO IMPROVING PACKAGE C TUTORS' COMPETENCE}

\begin{abstract}
This study aims at finding a model of Sustainable Technical Assistance that can improve the Package $C$ tutors'competence. The alternative model selected to achieve the research objective was by developing a model based on Sustainable Technical Assistance and focusing on the tutors'technical ability to perform their instructional tasks. The development of this model was based on the assumption that the previous model was conducted partially, much oriented on cognitive aspect, and conducted in conventional ways, and the content did not fit to the participants' needs. The Sustainable Technical Assistance model was developed applying research and development approach. The results showed that the model needs to be tried out to improve the pedagogical competence of Package $C$ tutors at the national standard.
\end{abstract}

Keyword : Model of Sustainable Technical Assistance, competence, and andragogy

\section{PENDAHULUAN}

Sejalan dengan Undang-Undang Republik Indonesia Nomor 20 Tahun 2003 tentang Sistem Pendidikan Nasional menyatakan bahwa: "Pendidikan nasional berfungsi mengembangkan kemampuan dan membentuk watak serta peradaban bangsa yang bermartabat dalam rangka mencerdaskan kehidupan bangsa, bertujuan untuk mengembangkan potensi peserta didik agar menjadi manusia yang beriman dan bertakwa kepada Tuhan Yang Maha Esa, berakhlak mulia, sehat, berilmu, cakap, kreatif, mandiri, dan menjadi warga negara yang demokratis serta bertanggung jawab".

Pendidikan merupakan faktor penting dalam meningkatkan kualitas sumber daya manusia. Oleh karena pendidikan diselenggarakan melalui jalur formal, non-formal, dan informal, ketiga jalur pendidikan itu diselenggarakan untuk melayani semua warga negara berdasarkan pada prinsip pendidikan sepanjang hayat menuju terbentuknya manusia pembelajar Indonesia. Pendidikan non-formal (PNF) salah satu programnya adalah pendidikan kesetaraan (program paket A setara SD, program B setara SLTP dan program paket $C$ setara $S M U)$.

Permasalahan yang dihadapi dalam peningkatan kualitas layanan pendidikan kesetaraan tertumpu pada tenaga tutor, hasil penelitian strategi nasional yang berjudul Pengembangan Model Pelatihan Berbasis Kinerja Tutor Paket $C$ pada Pusat Kegiatan Belajar Masyarakat di DKI Jakarta, menunjukkan bahwa : (1) kualifikasi pendidikan tutor 
kelompok belajar paket C sebanyak $70 \%$ belum S1, (2) kompetensi tutor paket $\mathrm{C}$ yang tidak sesuai dengan bidang keilmuannya baru $60 \%$, dan (3) dalam meningkatkan komptensi tutor kelompok belajar paket $\mathrm{C}$ adalah melalui pelatihan yang dilaksanakan secara konvensional (Anan: 2010). Dari tiga masalah pokok tersebut berdampak terhadap rendahnya (1) kemampuan tutor kelompok belajar paket $\mathrm{C}$ dalam melaksanakan proses pembelajaran; (2) penguasaan materi pembelajaran bagi tutor kelompok belajar paket C; (3) strategi, metode dan teknik pembelajaran yang digunakan tutor kelompok belajar paket C; dan (4) kemampuan tutor kelompok belajar paket $\mathrm{C}$ dalam melakukan evaluasi pembelajaran.

Strategi yang dipilih untuk mengatasi masalah tersebut, adalah melalui kegiatan bimbingan teknis berkelanjutan tutor paket C. Kajian secara empirik menunjukkan bahwa kontribusi hasil pelatihan berbasis kinerja tutor Paket C sebesar 34\% (Sutisna \& Sutaryat: 2010). Hal ini menunjukkan sangat lemahnya penguasaan kompetensi tutor paket $\mathrm{C}$ oleh karena itu dalam penyusunan materi bimtek berkelanjutan harus sesuai dengan apa dirasakan dan dibutuhkan oleh peserta, sehingga hasilnya bisa dimanfaatkan untuk mendukung pelaksanaan tugas tutor. Oleh karena itu, perlu adanya pengembangan model Bimtekber berkelanjutan untuk meningkatkan kompetensi tutor paket $\mathrm{C}$ pada Pusat Kegiatan Belajar Masyarakat (PKBM) .

Dalam penelitian ini rumusan masalahnya adalah "Bagaimana model konseptual bimbingan teknis berkelanjutan untuk meningkatkan kompetensi tutor paket $\mathrm{C}$ pada Pusat Kegiatan Belajar Masyarakat di Provinsi DKI Jakarta" Secara operasional ada beberapa konsep yang perlu dijelaskan, antara lain yaitu: (a) model bimbingan teknis berkelanjutan adalah proses pemberian layanan pendidikan melalui berbagai bentuk kegiatan pembelajaran dalam rangka meningkatkan kompetensi Tutor Paket C; (b) tutor Paket $\mathrm{C}$ adalah tenaga profesional yang bertugas merencanakan, melaksanakan proses pembelajaran, dan menilai hasil pembelajaran, serta melakukan pembimbingan bagi peserta didik kesetaraan Paket C; (c) kompetensi tutor Paket C adalah seperangkat pengetahuan, keterampilan, dan perilaku yang harus dimiliki, dihayati dan dikuasai oleh tutor dalam melaksanakan tugas keprofesiannya yang meliputi kompetensi pedagogik, profesional, kepribadian dan sosial; serta (d) peningkatan kompetensi tutor Paket $\mathrm{C}$ adalah upaya yang dilakukan secara sistematis dan sistemik oleh lembaga yang berwenang dalam rangka meningkatkan pengetahuan, keterampilan dan perilaku tutor dalam melaksanakan tugas keprofesiannya.

Kajian beberapa sumber pustaka menguatkan adanya beberapa teori yang digunakan untuk mengembangkan model bimbingan teknis berkelanjutan untuk meningkatkan kompetensi ini, yaitu (a) teori andragogi dan (b) teori kompetensi (competency theory).

Pendidikan orang dewasa harus mengacu pada kebutuhan belajar warga belajar dengan melibatkan warga belajar sebagai subjek belajar. Pelibatan warga belajar dalam proses pembelajaran didasarkan pada kenyataan bahwa peserta belajar memiliki kekayaan pengalaman (the role of the learner's experience) yang dapat dijadikan sebagai bahan pembelajaran, memilki konsep diri (the self concept) yang kuat dalam memerankan diri dalam berbagai kehidupan, memiliki kesiapan belajar yang khas (the readiness to learn) sesuai dengan minat dan kebutuhannya, orientasi belajar yang berbeda dengan anak kecil (orientasion to learning) sehingga diperlukan strategi pembelajaran yang sesuai dengan karakteristiknya, memilki kebutuhan akan pengetahuan (the need to know) dan motivasi (motivation) (Knowles, 1979).

Kebutuhan belajar dalam konteks pelatihan bukan hanya sosok kebutuhan individual sebagai calon peserta pelatihan akan tetapi menyangkut kebutuhan yang real dalam institusi. Di sini pelatihan melibatkan berbagai sumber, fasilitas, orang-orang yang terlibat dan saling berinteraksi, perlengkapan material, lingkungan sosial yang terorganisasi. Oleh karena itu, pelatihan tutor Paket $\mathrm{C}$ sebagai bentuk dari pendidikan nonformal dapat dilakukan dengan melibatkan peserta pelatihan secara aktif baik secara individual maupun klasikal.

Berkaitan dengan teori andragogi tersebut dapat disimpulkan bahwa pelatihan efektif dapat dicapai apabila proses pelatihan melibatkan aktivitas mental dan fisik peserta pelatihan secara sungguh-sungguh dan konsisten dalam setiap pentahapan pelatihan. Menurut teori ini, orang dewasa dapat menentukan apa yang akan dipelajari, dimana dan bagaimana cara mempelajarinya, serta kapan melakukan kegiatan belajar dengan melibatkan pikiran dan perbuatan. Implikasinya, dalam pelatihan orang dewasa akan belajar secara efektif dengan melibatkan fungsi otak kiri dan otak kanan, menggunakan kemampuan intelek dan emosi serta dengan memanfaatkan 
berbagai media, metode, teknik dan pengalaman belajar yang sesuai dengan karakteristiknya.

Strategi pelaksanaan bimbingan teknis berkelanjutan menggunakan pendekatan andragogi seperti pada gambar 1 berikut.

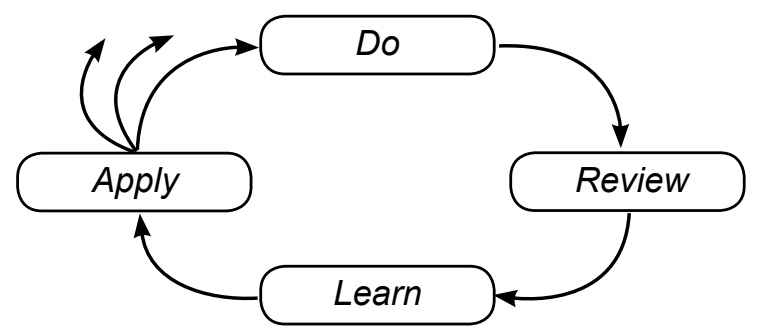

Gambar 1. Siklus pendekatan adragogi

Orang dewasa diasumsikan pernah melakukan (do) pekerjaan sehingga ketika mengikuti diklat, mereka sudah memiliki pengalaman kerja. Fasilitator memfasilitasi peserta diklat untuk mereview pengalaman masing-masing dan saling berbagi pengalaman baik antara peserta maupun peserta dengan fasilitator. Peserta saling mempelajari (learn) kelebihan dan kelemahan berdasarkan hasil review dan fasilitator memfasilitasi hasil belajar peserta dengan penguatan/pengayaan berupa konsep/teori/ prinsip/sikap/pengalaman praktik (Sudjana, 2007). Akhirnya, peserta menerapkan (apply) hasil diklatnya baik pada saat penugasan fasilitator pada saat diklat maupun setelah kembali ke tempat tugas. Ketika menerapkan hasil diklat, peserta dapat melakukan (do) sesuai dengan yang diharapkan dan mungkin pula hasil diklat tidak dapat diterapkan di tempat tugas atau terjadi penyimpangan-penyimpangan.

Metode yang digunakan dapat bervariasi agar dapat membantu orang dewasa belajar secara efektif. Pelaksanaan bimbingan teknis berkelanjutan tutor Paket $\mathrm{C}$ berdasarkan kompetensi yang harus dimiliki oleh setiap peserta diklat sehingga setelah mereka mengikuti program pelatihan ini akan mampu melakukan sesuatu (the ability to do something). Jadi, kurikulum, penyelenggaraan, dan evaluasi mengacu pada kompetensi yang harus dimiliki agar peserta mampu menjalankan tugas pokok dan fungsinya. Mengingat setelah mengikuti program penguatan kompetensi peserta harus mampu melakukan sesuatu, maka proses pembelajaran yang tepat adalah menggunakan experiential learning yang jenisjenisnya banyak, misalnya curah pendapat, refleksi diri, praktik, magang, bekerja, diskusi kelompok dan kelas, simulasi, penugasan individual, bermain peran, dan sebagainya. Pelaksanaan Bimbingan teknis berkelanjutan akan efektif, efisien, dan tidak membosankan jika hasil-hasil belajar dari pengalaman sebelumnya diakui sebagai dasar penetapan peserta program bimbingan teknis berkelanjutan.

Kompetensi didefinisikan (Mitrani et.al, 1992; and Spencer,1993) sebagai anunderlying characteristic's of an individual which is causally related to criterion-referenced effective and or superior performance in a job or situation. Pengertian tersebut menjelaskan karakteristik yang mendasari seseorang dan berkaitan dengan efektivitas kinerja individu dalam pekerjaannya. Berangkat dari pengertian tersebut kompentensi seorang individu merupakan sesuatu yang melekat dalam dirinya yang dapat digunakan untuk memprediksi tingkat kinerjanya. Sesuatu yang dimaksud bisa menyangkut motif, konsep diri, sifat, pengetahuan maupun kemampuan atau keahlian. Kompentensi individu yang berupa kemampuan dan pengetahuan bisa dikembangkan melalui pelatihan.

Kompetensi dapat terbagi atas dua kategori yaitu "threshold competencies" dan "differentiating compentencies" (Spencer; 1993). Threshold competencies adalah karakteristik utama yang harus dimiliki oleh seseorang agar dapat melaksanakan pekerjaannya. Tetapi tidak untuk membedakan seorang yang berkinerja tinggi dan rata-rata. Sedangkan "differentiating competiencies" adalah faktor-faktor yang membedakan individu yang berkinerja tinggi dan rendah. Misalnya seorang tutor harus mempunyai kemampuan utama mengajar, itu berarti pada tataran "threshold competencies", selanjutnya apabila dosen dapat mengajar dengan baik, cara mengajarnya mudah dipahami dan analisisnya tajam sehingga dapat dibedakan tingkat kinerjanya maka hal itu sudah masuk kategori "differentiating competencies".

Kompetensi tutor terdiri atas dua kelompok yakni kompetensi generik dan kompetensi spesifik. Kompetensi generik meliputi kompetensi pedagogik, kepribadian dan sosial, sedangkan kompetensi spesifik adalah kompetensi profesional. Kompetensi generik berlaku untuk semua jenis tutor, sementara kompetensi spesifik berlaku untuk masing-masing jenis tutor. Adapun elemen kompetensi tutor pendidikan kesetaraan (paket $\mathrm{C}$ ) adalah sebagai berikut.

Pertama, pedagogik dan andragogik: (1) memahami karakteristik, peserta didik, (2) menguasai konsep pendidikan, (3) menguasai pengembangan 
kurikulum, (4) menguasai strategi pembelajaran, (5) menciptakan situasi pembelajaran, (6) menguasai strategi bimbingan belajar peserta didik, (7) menguasai media pembelajaran dan (8) menguasai prosedur penilaian proses dan hasil belajar. Kedua, kepribadian: (1) menampilkan diri sebagai pribadi yang jujur, berwibawa dan bijaksana, (2) berakhlak mulia dan menjadi teladan bagi peserta didik, (3) memiliki jiwa, sikap, dan perilaku demokratis, (4) memiliki komitmen terhadap profesi. Ketiga, sosial: (1) bersikap terbuka, objektif, dan tidak diskriminatif, (2) berkomunikasi secara efektif dan santun dengan peserta didik. (3) berkomunikasi secara santun dengan sesama tutor dan tenaga kependidikan, (4) berkomunikasi santun dengan orangtua/wali peserta didik serta masyarakat sekitar, (5) beradaptasi dengan kondisi sosial budaya setempat dan (6) bekerja sama dengan peserta didik, sesama tutor dan tenaga kependidikan. Keempat, profesional: (1) menguasai materi pembelajaran, (2) menguasai konsep dan teori yang menaungi substansi, (3) memetakan hubungan substansi antar mata pelajaran, (4) memetakan hubungan antara substansi dengan kehidupan, dan (5) memanfaatkan TIK untuk pengembangan diri (BSNP, 2008).

\section{METODE PENELITIAN}

Untuk mencapai tujuan penelitian ini ditempuh dengan pendekatan penelitian dan pengembangan (research and development).Lokasi penelitian adalah Provinsi DKI Jakarta (Dinas Pendidikan / Sudin Dikmen Kota Jakarta Pusat dan Timur). Penelitian dilaksanakan pada bulan Juli sampai dengan November 2015. Subjek Penelitian adalah tutor kelompok belajar Paket $\mathrm{C}$ aktif, kualifikasi pendidikan S1 dan umur maksimum 35 tahun.

Prosedur penelitian mengacu pada guide-line Borg dan Gall, ada sepuluh tahapan yang harus ditempuh dalam $R$ \& D. Kesepuluh langkah itu secara sederhana adalah: (1) peneliti mengumpulkan informasi, termasuk membaca literatur, mengobservasi kelas, dan menyiapkan laporan tentang kebutuhan pengembangan; (2) merencanakan prototype komponen yang akan dikembangkan; (3) mengembangkan prototype awal; (4) melakukan ujicoba terbatas terhadap model awal; (5) merevisi model awal; (6) melakukan ujicoba lapangan. (7) melakukan revisi produk; (8) melakukan ujicoba lapangan secara operasional. (9) melakukan revisi akhir terhadap model, dan (10) melakukan diseminasi dan penyebaran kepada berbagai pihak. Dalam penelitian ini, kesepuluh langkah tersebut dimodifikasi menjadi empat tahapan sebagai berikut.

1. Studi Pendahuluan Mengeksplorasi Model Bimtek yang telah ada.

Studi pendahuluan dilakukan untuk mengetahui dan mendalami model-model bimtek yang dilakukan sekarang di lembaga penyelenggara di propinsi DKI Jakarta dan di Pusat dalam hal ini Sudit PTK Direktorat Pendidikan Menengah. Persoalan yang dieksplorasi dalam studi pendahulan tersebut meliputi (1) model - model bimtek program paket $\mathrm{C}$ yang yang dilakukan sekarang, (2) metode dan strategi bimtek yang dilakukan penyelenggara maupun tutor, (3) aktivitas peserta dalam mengikuti kegiatan bimtek, (4) peranan tutor dalam pengelolaan dan pengendalian bimtek, (5) kegiatan bimtek yang diinginkan oleh peserta didik, (6) kegiatan penilaian dalam bimtek, serta (7) tindak lanjut bimtek.

Untuk kepentingan studi pendahuluan, metode pengumpulan data utama adalah observasi partisipasi, wawancara mendalam dan studi dokumentasi. Untuk teknik analisis data menggunakan deskriptik yaitu memaparkan fenomena pelaksanaan bimbingan teknis yang dilakukan sekarang pada lembaga penyelenggara bimbingan teknis.

\section{Penyusunan Model Konseptual}

Pengembangan model konseptual dilakukan dengan prosedur (1) penentuan komponen model berdasarkan informasi teoretik, dan (2) validasi ahli dan praktisi. Penentuan komponen model dilakukan dengan cara mengkaji secara kritis hasil-hasil studi pendahuluan dan ekplorasi lapangan terdahulu, menarik preskripsi dari kajian literatur tentang model bimtek, khususnya teori dan praktik bimtek di lembaga penyelenggara program paket $\mathrm{C}$. Hasil temuan model tersebut selanjutnya dilakukan uji akurasi dan implementasi dengan melibatkan ahli di bidang pembelajaran bimtek untuk memantapkan bangunan model secara keseluruhan. Komponen model yang dikembangkan terdiri dari (1) rencana program bimbingan teknis, (2) materi bimbingan teknis, dan (3) pengelolan pembelajaran bimbingan teknis yang meliputi peran peserta didik, peran tutor dalam pembelajaran, strategi, media, penilaian dan bentuk tindak lanjut kegiatan bimbingan teknis.

Metode pengumpulan data yang diterapkan adalah angket dan wawancara mendalam serta 
focus group discussion (FGD). Untuk teknik analisis data menggunakan triangulasi dan verifikasi teknik delphi dengan pihak sumber data dan auditor data yang dinilai kredibel. Tahapan ini dilakukan pada tahun pertama dengan target luaran menghasilkan model konseptual pembelajaran untuk peningkatan kemandirian belajar.

3. Perangkat dan Substansi Model Bimtekber untuk Diimplementasikan

Pengembangan perangkat dan substansi model dilakukan dengan prosedur (1) identifikasi perangkat dan isi model, (2) pengembangan perangkat dan substansi model, dan (3) validasi ahli dan uji-coba perangkat model. Identifikasi perangkat dan substansi model dilakukan dengan cara menganalisis karakteristik bimtek, dan secara simultan dikaitkan dengan peningkatan komptensi yang telah disiapkan sebelumnya. Uji-coba perangkat model dilakukan dengan metode limited field-trial dengan bekerjasama dengan beberapa lembaga penyelenggara bimtek peningkatan kompetensi tutor paket $C$ yang ada di provinsi DKI Jakarta

Metode pengumpul data yang diterapkan adalah angket dan wawancara, serta focus group discussion (FGD). Untuk teknik analisis data menggunakan triangulasi dan verifikasi dengan teknik delphi dengan pihak sumber data dan auditor data yang dinilai kredibel. Target luaran menghasilkan model Bimtekber untuk peningkatan komptensi tutor yang telah dicobakan dalam kalangan terbatas.

4. Uji Efektivitas Model melalui Tindakan Berulang untuk Memperoleh Baku Mutu Model Bimtekber yang Kredibel

Uji coba model yang lebih luas untuk mengetahui efektivitas model melalui tindakan berulang dilakukan dengan berdasar pada pendapat Hopkins (1993) yang meliputi kegiatan (1) perencanaan strategi implementasi bimtek, (2) pelaksanaan bimtek, (3) refleksi hasil dan proses bimtek, dan (4) observasi serta perbaikan proses bimtek. Dalam siklus bimtek ini diperlukan dua kali siklus pelaksanaan bimtek dengan peserta didik yang berbeda dan lembaga bimtek yang berbeda pula. Pertama dilakukan di Provinsi DKI Jakarta yang ada dalam Dinas Pendidikan, Kedua dilakukan di Subdit Pendidik dan Tenaga Kependidikan Direktorat Pendidikan Menengah sehingga dimungkinkan adanya variasi dan akurasi data yang lebih lengkap untuk memperbaiki model bimtek yang dianggap efektif dalam peningkatan kompetensi tutor yang diharapkan.

Metode pengumpulan data yang diterapkan adalah angket dan wawancara, serta tes hasil bimtek (pretest and posttest). Untuk teknik analisis data menggunakan triangulasi dan dan teknik uji statistik (Soegiyono, 2007). Target luaran menghasilkan Model Bimtekber untuk peningkatan kompetensi tutor yang efektif yang dapat digunakan dalam kalangan lebih luas.

Teknik analisis data dilakukan secara kualitatif dan kuantitatif, terhadap implementasi model bimtek. Analisis kualitatif digunakan untuk mendeskripsikan hasil penelitian pendahuluan, analisis kuantitatif terkait dengan keterlaksanaan dan pengaruh model yang dikembangkan. Analisis kuantitatif digunakan untuk menganalisis perbedaan (gain) penguasaan kompetensi sesuai komponennya sebelum implementasi model (pretest), dengan penguasaan kompetensi setelah implementasi model (posttest). Selanjutnya dikomparasikan hasil pretest dan posttest antara tutor kelompok treatment dengan tutor kelompok kontrol. Dengan demikian akan dapat ditentukan besarnya "perbedaan murni" (net gain), gain dimaknai besarnya peningkatan kompetensi tutor yang lebih meyakinkan sebagai pengaruh dari implementasi model bimtek yang dikembangkan. Pengaruh implementasi model imtek terhadap peningkatan kompetensi ditunjukkan berdasarkan perbandingan gain skor kelompok treatment dengan gain skor kelompok kontrol yaitu sebagai net gain (Kirkpatrick, 2006).

\section{HASIL DAN PEMBAHASAN}

\section{Deskripsi Data}

Tujuan penelitian ini adalah untuk mengumpulkan berbagai informasi yang dianggap relevan mendukung pengembangan model Bimbingan Teknis/ Pelatihan berkelanjutan untuk meningkatan kompetensi pedagogik dan andragogik tutor paket C. Studi pendahuluan ini dilakukan melalui pengumpulan informasi berkaitan dengan:
(1) hasil-hasil penelitian lain yang relevan dengan model Bimbingan Teknis/ Pelatihan yang akan dikembangkan, (2) teori-teori yang mendukung terhadap pengembangan model Bimbingan Teknis/ Pelatihan, (3) analisis kesenjangan antara kondisi faktual dengan permasalahan aktual yang dihadapi tutor dalam melaksanakan tugas pembelajaran, dan (4) analisis kompetensi pedagogik dan andragogik 
tutor kesetaraan paket $C$ yang seharusnya.

Kegiatan studi ini dilakukan dengan menggunakan teknik: (1) Focus Group Discusion dengan Kepala Bidang Pendidikan Nonformal dan Informal di Provinsi DKI Jakarta khususnya seksi pendidikan kesetaraan dan pengelola Bimbingan Teknis di DKI Jakarta tentang pengembangan kompetensi tutor paket paket C, (2) survei terhadap tutor paket $\mathrm{C}$ sebagai peserta bimtekber dengan tujuan untuk memperoleh informasi tentang kualifikasi dan kompetensi tutor dalam melakukan kegiatan pembelajaran dan sekaligus untuk menyusun kondisi objektif kompetensi tutor, (3) survei di PKBM 15 Cideng dan PKBM Al Ishlah Jakarta Pusat. Kemudian PKBM Miftahul Jannah dan PKBM 32 Duren Sawit Jakarta Timur, di mana PKBM tersebut yang ditentukan sebagai sampel penelitian.

Survei yang dilakukan PKBM di DKI Jakarta tersebut ditempuh melalui kegiatan studi dokumen, wawancara, dan pengamatan terhadap tutor dalam pembelajaran. Studi dokumen pada kegiatan survei di PKBM dimaksudkan untuk mengetahui data umum PKBM, data warga belajar program pendidikan kesetaraan khususnya paket $\mathrm{C}$, data ketenagaan (tutor) PKBM, data sarana dan prasarana PKBM, data kurikulum dan kegiatan pembelajaran. Secara keseluruhan kegiatan studi yang dilakukan bertujuan untuk: (1) mengetahui kondisi objektif tutor berkenaan dengan kualifikasi akademik dan profil kompetensinya dan (2) model bimtek dan strategi pengembangan kompetensi tutor khususnya paket C di Provinsi DKI Jakarta.

Hasil pengumpulan data dan informasi, kajian teori serta kajian hasil penelitian lainnya yang sejenis. Kemudian hasil studi dijadikan acuan melakukan analisis dalam merumuskan konsep model awal Bimbingan Teknis ini. Temuan hasil studi berdasarkan tahap kegiatan yang ditempuh dan tujuan yang hendak dicapai, diuraikan lebih lanjut sebagai berikut. 1. Kondisi Objektif Kualifikasi Pendidikan Tutor

Studi dokumen pada kegiatan studi di Bidang Pendidikan Non Formal dan Informal, yaitu melalui Kepala seksi Pendidikan Kesetaraan. Di DKI Jakarta tercatat data tentang PKBM penyelenggara program paket $\mathrm{C}$ tahun 2011 yang melaksanakan pendidikan kesetaraan sebanyak 144 PKBM yang tersebar di Jakarta, dengan jumlah tutor 422 orang tutor dengan berbagai kualifikasi pendidikan yang beragam mulai dan kualifikasi SLTA, Diploma (D3), S1.dan S2. Kondisi objektif kualifikasi pendidikan tutor berdasarkan data sebagaimana tersebut dapat dilihat dalam gambar 2 berikut.

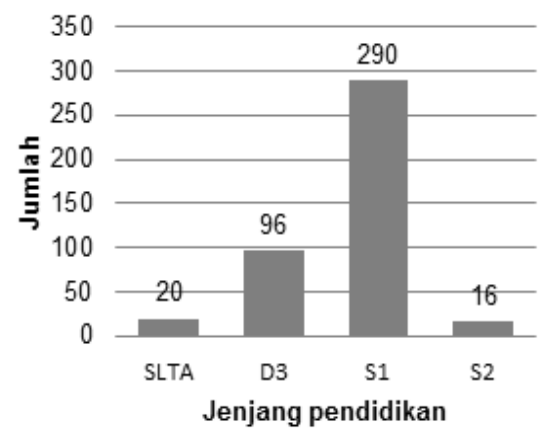

Gambar 2. Grafik kualifikasi pendidikan tutor

Dengan memperhatikan grafik pada gambar 2, maka persentase tertinggi kualifikasi tutor adalah kualifikasi SI 290 orang (68.72\%). Data kualifikasi pendidikan tersebut umumnya dari Sarjana Non Kependidikan. Kualifikasi Diploma/Sarjana muda (D3) 96 orang (22,74\%). Kualifikasi SLTA 20 orang $(4,73 \%)$ dan kualifikasi S2 sebanyak 16 orang $(3,79 \%)$. Kondisi objektif kualifikasi pendidikan tutor paket $\mathrm{C}$, menunjukkan bahwa kualifikasi (qualifled) dan terjadinya ketidakcocokan (miss-match) antara keahlian tutor dengan bidang tugas mengajarnya pada pendidikan kesetaraan paket $\mathrm{C}$ di PKBM tersebut, serta ditambah dengan latar belakang pendidikan tutor $69 \%$ Sarjana non kependidikan.

\section{Kondisi Objektif Kompetensi Pedagogik Tutor}

Hasil survei terhadap tutor kesetaraan paket C yang telah mengikuti bimtek, pada bidang Pendidikan Nonformal dan Informal Provinsi DKI Jakarta pada bulan Juli 2013, dari 30 orang tutor masing-masing mewakili PKBM di DKI Jakarta, diperoleh: 3 orang tutor (10\%) berkualifikasi Diploma/Sarjana Muda (D3), 27 orang tutor (90\%) berkualifikasi Sarjana (S1). Temuan tersebut juga menunjukkan sebagian besar tutor kualifikasinya sudah qualified dan hanya keahlian mengajarnya yang masih miss-match. Kondisi ini makin menunjukkan indikasi bahwa mutu pembelajaran dalam penyelenggaraan paket $C$ pada PKBM lemah, dan sangat perlu adanya pengembangan dan peningkatan kompetensi tutor di PKBM.

Untuk memperoleh gambaran tentang kondisi objektif kompetensi tutor, pada kegiatan studi ini melakukan survei terhadap 30 orang tutor peserta bimtek, yang masing-masing sebagai perwakilan dari masing-masing PKBM di DKI Jakarta. Deskripsi tentang profil kompetensi tutor diangkat dari jawaban 
tutor melalui kuesioner yang diberikan kepada mereka. Data objektif kompetensi tutor yang dijaring dengan empat aspek.

Pertama, aspek perencanaan pembelajaran data menunjukkan seperti pada gambar 3 berikut.

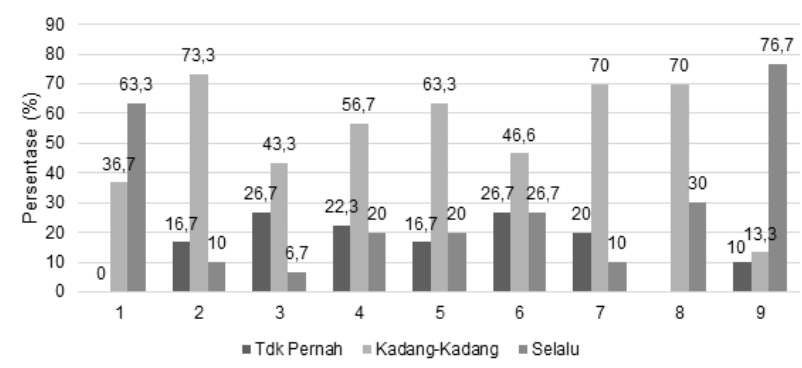

Gambar 3. Grafik perencanaan pembelajaran

Dengan memperhatikan grafik pada gambar 3, maka (1) kesempatan mengikuti bimtek untuk meningkatkan kompetensi sebesar $73,3 \%$; (2) memahami kurikulum program paket $c$ yang diselenggarakan di PKBM sebesar 10\%; (3) biasa menyusun program tahunan berdasarkan kurikulum program paket c sebesar $6,7 \%$; (4) biasa menyusun program semester dalam melaksanakan pembelajaran sebesar 20\%; (5) biasa menyusun silabus mata pelajaran yang diajarkansebesar $20 \%$; (6) biasa membuat rencana program pembelajaran sebesar 26,7\%; (7) menjabarkan kurikulum ke dalam program tahunan dan program semester sebesar $10 \%$; (8) memahami penyusunan rencana program pembelajaran sebesar $20 \%$; dan (9) membuat RPP dengan mempertimbangkan karakteristik warga belajar sebesar $76,7 \%$.

Kedua, aspek pengorganisasian pembelajaran data menunjukkan seperti pada Gambar 4 berikut.

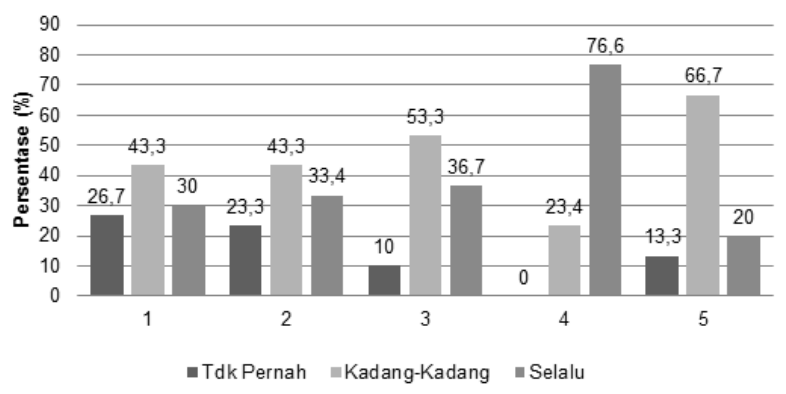

Gambar 4. Pengorganisasian pembelajaran

Dengan memperhatikan grafik pada gambar 4, maka (1) menyusun bahan ajar sendiri ketika melakukan tugas mengajar sebesar $30 \%$; (2) menyusun ringkasan materi pada setiap mengajar sebesar 33,4\%; (3) biasa menyusun rencana bimbingan warga belajar sebesar $36,7 \%$; (4) menyusun rencana tertulis pengumpulan data hasil belajar sebesar $76,6 \%$; dan (5) mengembangkan media belajar sendiri sebesar $20 \%$.

Ketiga, aspek pelaksanaan proses pembelajaran data menunjukkan seperti pada gambar 5 berikut.

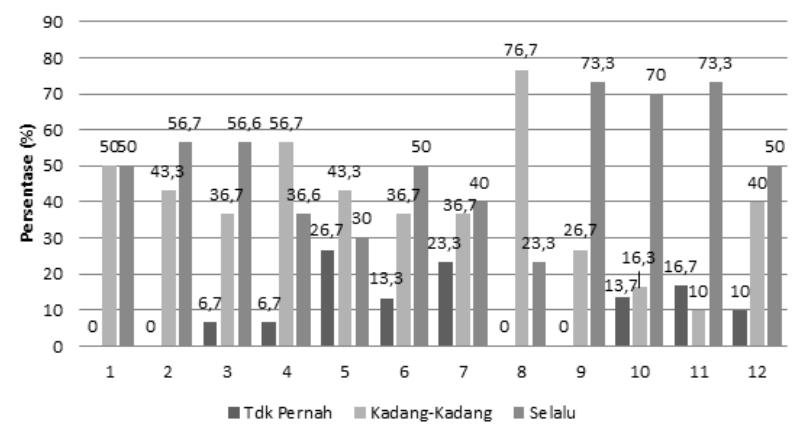

Gambar 5. Pelaksanaan pembelajaran

Dengan memperhatikan grafik pada gambar 5, maka (1) biasa menggunakan media dan sarana pendukung sebesar 50\%; (2) mengembangkan berbagai sumber belajar dalam mengajar sebesar $56,7 \%$, (3) membuat media sendiri untuk efektivitas pembelajaran sebesar $56,6 \%$; (4) melaksanakan bimbingan dan konseling untuk warga belajar program paket $C$ sebesar $36,6 \%$; (5) mengajar berdasarkan rencana program pembelajaran yang telah disusun sebesar $30 \%$; (6) pembelajaran dilakukan secara sistematis sebesar $50 \%$; (7) menggunakan metode yang bervariasi sebesar 40\%; (8) mengajar biasa memberikan latihan kepada warga belajar sebesar $23,3 \%$; (9) menggunakan kiat-kiat membangkitkan motivasi belajarsebesar $73,3 \%$; (10) interaktif antara tutor dengan warga belajar sebesar $70 \%$; (11) memanfaatkan teknologi informasi dalam pembelajaran di program paket $\mathrm{C}$ sebesar $73,3 \%$; dan (12) memanfaatkan sumber belajar yang ada di sekitar lingkungan belajar paket C sebesar $50 \%$.

Keempat, aspek penilaian hasil belajar data menunjukkan seperti pada gambar 6 berikut.

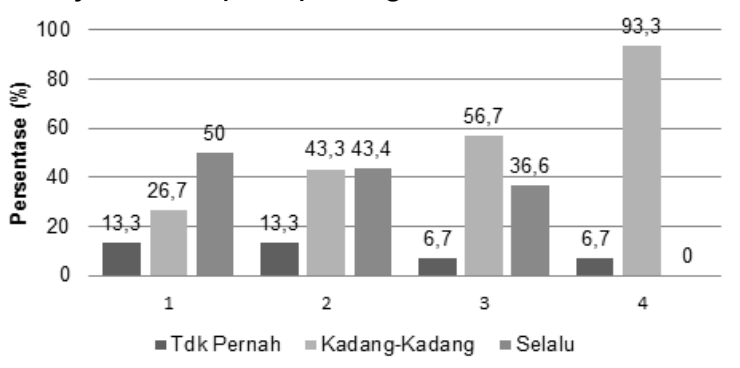

Gambar 6. Penilaian hasil belajar 
Dengan memperhatikan grafik pada gambar 6, maka: (1) biasa menyusun tes hasil belajar untuk setiap unit materi sebesar $50 \%$; (2) melakukan evaluasi formatif pada setiap akhir pembelajaran sebesar 43,4\%; (3) memberikan layanan bimbingan kesulitan belajar warga belajar sebesar $36,6 \%$; dan (4) mengetahui hasil belajar warga belajar jelek memberikan pembelajaran remedial.

Berdasarkan analisis data kondisi objektif kompetensi pedagogik dan andragogik tutor pendidikan kesetaraan paket $C$ pada PKBM, pada sampel yang disurvei ketika studi pendahuluan menunjukkan penguasaan kompetensi pedagogik dan andragogik tutor rata-rata hanya $40,3 \%$. Profil kompetensi tutor diketahui berdasarkan pemahaman dan persepsi tutor terhadap indikator kompetensi.

\section{B. Model Konseptual Bimbingan Teknis Berkelanjutan}

Kerangka konsep model peningkatan kompetensi tutor Paket $\mathrm{C}$ melalui Bimbingan teknis berkelanjutan ada lima komponen yang harus diperhatikan terlebih dahulu yaitu: (1) penetapan kondisi ideal kompetensi tutor Paket $\mathrm{C}$ berdasarkan atas standar nasional pendidikan, (2) identifikasi dan pemetaan kondisi objektif kompetensi sesuai dengan standar nasional pendidikan, (3) pembinaan dan pengembangan profesionalitas tutor $P$ aket $C$, (4) pelaksanaan Bimbingan teknis berkelanjutan dalam meningkatkan kompetensi tutor Paket C, dan (5) evaluasi pasca Bimtekber.

Dengan memperhatikan lima komponen tersebut, maka ada beberapa karakteristik dasar yang perlu dipertimbangkan dalam bimbingan teknis berkelanjutan yaitu (1) berkeadilan (equitable), yang memiliki makna bahwa bimbingan teknis berkelanjutan tutor Paket $\mathrm{C}$ seyogyanya mempertimbangkan prioritas layanan tidak bertentangan dengan peraturan yang berlaku, (2) tangguh (bearable), yang mengandung makna bahwa Bimtekber tutor Paket $C$ sebaiknya mengacu pada kondisi ideal dan memecahkan persoalan pada kondisi objektif, (3) dinamis, yang mengandung makna Bimtekber tutor Paket $C$ sebaiknya mempertimbangkan kondisi objektif berpendekatan andragogis yang fleksibel dan (4) berkelanjutan (sustainable), yang mengandung makna bahwa Bimtekber tutor Paket $\mathrm{C}$ harus dilaksanakan secara berkesinambungan dengan mempertimbangkan sinergitas kondisi objektif dan ideal secara tangguh, berkeadilan dan dinamis.

Berdasarkan keempat karakteristik dasar tersebut, maka setiap komponen dapat dielaborasi sebagai berikut. Pertama, analisis terkendali terhadap kondisi ideal kompetensi tutor Paket $\mathrm{C}$ harus dilakukan secara cermat dan memadai. Kondisi ideal itu mengacu kepada standar nasional pendidikan, khususnya kompetensi tutor Paket $\mathrm{C}$. Kedua, pemetaan dan analisis terkendali terhadap kondisi objektif kompetensi tutor harus dilakukan sehngga diperoleh profil kebutuhan pembinaan dan pengembangan kompetensi tutor sebagai bahan kajian penyusunan strategi bimbingan teknis berkelanjutan. Ketiga, kegiatan bimbingan teknis berkelanjutan dalam pelaksanaannya harus memperhatikan empat aspek penting yaitu: (1) prinsip dasar peningkatan kompetensi, (2) strategi peningkatan kompetensi, (3) lingkup program peningkatan kompetensi, dan (4) pola-pola pembinaan kompetensi. Keempat, hasil bimbingan teknis berkelanjutan adalah tutor yang memiliki kompetensi dalam melaksanakan tugas profesionalnya. Penilaian terhadap pemenuhan kriteria sebagai tutor yang kompeten harus disesuaikan dengan sifat dan ciri pendidik nonformal. Kelima, evaluasi pasca bimbingan teknis berkelanjutan dapat dilakukan melalui evaluasi dampak program.

Pola Bimtekber melalui diklat, workshop/ seminar/lokakarya, magang, tutorial, belajar mandiri dan focus group discussion dan prinsip bimbingan teknis berkelanjutan adalah (1) berbasis kebutuhan, (2) terencana dan sistematis, (3) berkelanjutan, (4) fleksibel, (5) adatif dan (6) situasional. Secara visual tersaji pada gambar 7 .

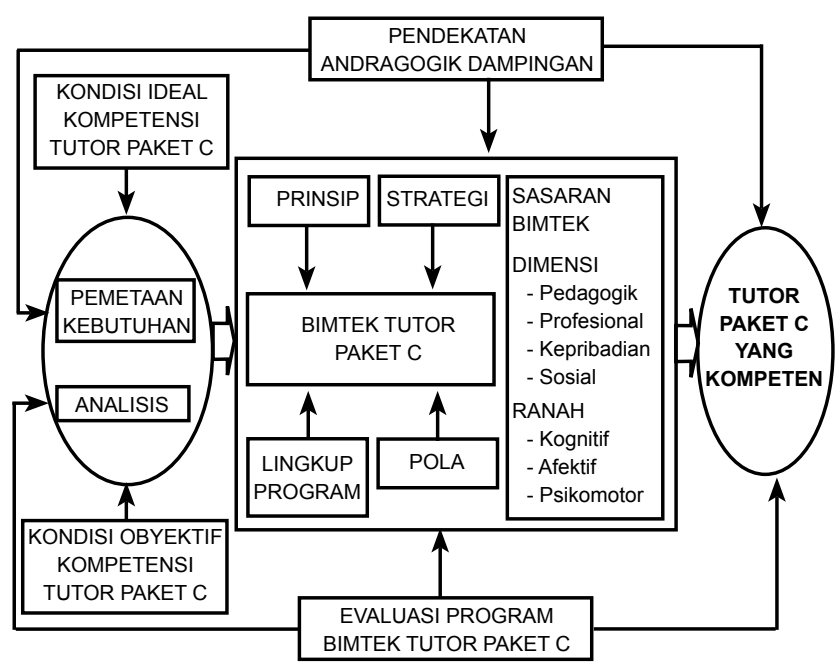

Gambar 7. Sistem pelaksanaan bimtekber tutor paket C 


\section{PENUTUP}

\section{Kesimpulan}

Berdasarkan hasil dan pembahasan penelitian, maka dapat disimpulkan sebagai berikut. Pertama, kondisi objektif kualifikasi pendidikan tutor paket $\mathrm{C}$, menunjukkan bahwa kualifikasi (qualifled) dan terjadinya ketidakcocokan (miss-match) antara keahlian tutor dengan bidang tugas mengajarnya pada pendidikan kesetaraan paket $\mathrm{C}$ di PKBM, serta ditambah dengan latar belakang pendidikan tutor $69 \%$ Sarjana nonkependidikan. Kedua, hasil analisis menunjukkan penguasaan kompetensi pedagogik dan andragogik tutor rata-rata hanya 40,3\%. Profil kompetensi tutor diketahui berdasarkan pemahaman dan persepsi tutor terhadap indikator kompetensi. Ketiga, konseptual bimbingan teknis berkelanjutan terdapat lima komponen yaitu: (1) penetapan kondisi ideal kompetensi tutor Paket $\mathrm{C}$ berdasarkan atas standar nasional pendidikan, (2) identifikasi dan pemetaan kondisi objektif kompetensi tutor, (3) pola pembinaan dan pengembangan profesionalitas tutor Paket C, (4) pelaksanaan bimbingan teknis berkelanjutan dalam meningkatkan kompetensi tutor Paket $C$ dan (5) evaluasi pasca bimbingan teknis berkelanjutan.

\section{Saran}

Berdasarkan kesimpulan penelitian, beberapa saran dalam yang diajukan antara lain sebagai berikut, Pertama, perlu adanya pemetaan kualifikasi pendidikan tutor yang diiringi dengan kesesuaian antara bidang tugas mengajar tutor dengan bidang keahlian tutor yang akan dijadikan peserta bimbingan teknis berkelanjutan. Kedua, mengingat penguasaan kompetensi tutor paket $\mathrm{C}$ dalam pedagogik masih rendah maka diperlukan adanya uji kompetensi pedagogik sebelum diikutsertakan kegiatan bimbingan teknis berkelanjutan. Ketiga, karena model bimbingan teknis berkelanjutan ini masih pada tatanan pengembangan konsep maka diperlukan adanya ujicoba model bimbingan teknis secara lebih luas. Untuk melihat lebih jauh efektivitas model bimbingan teknis berkelanjutan dalam meningkatkan kompetensi tutor paket $\mathrm{C}$.

\section{DAFTAR PUSTAKA}

BSNP. (2008). Draf standar tutor pendidikan kesetaraan. Jakarta: Depdiknas.

Gall, M.D. Gall J.P. \& Borg W.R. (2003). Educational research an introduction. 7 th. Ed. Boston: Pearson Education, Inc.

Hopkins, D. (1993). A theacher's to guide classroom research. Philladelphia: Open University Press

Knowles, M. S. (1979). Andragogy in action: Applying modern principles of adult learning. San Francisco: Jossey Bass Inc.

Kirkpatrick, D. L. \& James D. (2006). Evaluating training programs. San Fransisco: BerretKohler Publisher Inc.

Mitrani,A., Daziel, M., \& Fitt, D. (1992). Competency based human resource management: valuedriven strategies for recruitment, development and reward. Kogan Page Limited: London. Spencer, M. L., \& Spencer, M. S. (1993). Competence at work: Models for superrior performance. New York: John Wily and Son, Inc.

Sugiyono. (2007). Metode penelitian kuantitatif, kualitatif dan $R \& D$. Bandung: Alfabeta

Sudjana, D. (2007). Sistem \& manajemen pelatihan teori \& aplikasi. Bandung : Fallah Production.

Sutisna, Anan. (2010). Pelatihan berbasis kinerja, konsep dan implementasi dalam pelatihan guru/tutor. Jakarta : FIP Press.

Sutisna, A.,\& Trisnamansyah, S. (2010). Model Pelatihan Berbasis Kinerja dalam Meningkat Kompetensi Tutor Pendidikan Kesetaraan. Yogyakarta. Jurnal Cakrawala Pendidikan Edisi. XXIX No. 3 